\title{
Protein Expression and Genetic Variation of IL32 and Association with Colorectal Cancer in Swedish Patients
}

\author{
LEVAR SHAMOUN $^{1}$, BLANKA KOLODZIEJ $^{2}$, ROLAND E. ANDERSSON $^{3,4}$ and JAN DIMBERG ${ }^{5}$ \\ ${ }^{1}$ Division of Medical Diagnostics, Department of Laboratory Medicine, and \\ Departments of ${ }^{2}$ Pathology and ${ }^{3}$ Surgery, Jönköping County, Jönköping, Sweden; \\ ${ }^{4}$ Department of Clinical and Experimental Medicine, \\ Faculty of Medicine and Health Sciences, Linköping University, Linköping, Sweden; \\ ${ }^{5}$ Department of Natural Science and Biomedicine, School of Health and Welfare, \\ Jönköping University, Jönköping, Sweden
}

\begin{abstract}
Background: Interleukin 32 (IL32) is an intracellular pluripotent cytokine produced by epithelial cells, monocytes, T-lymphocytes and natural killer cells and seems to be involved in the pathogenesis of cancer and inflammatory diseases. Our purpose was to assess the role of protein expression and genetic polymorphisms of IL32 in colorectal cancer (CRC) susceptibility. Materials and Methods: To gain insight into clinical significance of IL32 in Swedish patients with $C R C$, using enzyme-linked immunosorbent assay, we determined whether IL32 protein level is altered in CRC tissue $(n=75)$ compared with paired normal tissue and in plasma from patients with CRC (n=94) compared with controls $(n=81)$. The expression of IL32 protein was confirmed by immunohistochemistry ( $n=73$ ). We used Luminex technology to investigate protein levels of the cytokines IL6, tumor necrosis factor- $\alpha(T N F \alpha)$ and vascular endothelial growth factor (VEGF) to relate these to IL32 levels in CRC tissue. Three single nucleotide polymorphisms (SNPs) (rs28372698, rs12934561, rs4786370) of the IL32 gene have been proposed as modifiers for different diseases. The present study evaluated the susceptibility of patients possessing these SNPs to CRC. Using TaqMan SNP genotyping assays, these SNPs were screened in Swedish patients with CRC $(n=465)$ and healthy controls ( $n=331$ ). Results: We found no significant differences in the genotypic frequencies between the patients and healthy
\end{abstract}

This article is freely accessible online.

Correspondence to: Dr. Jan Dimberg, Department of Natural Science and Biomedicine, School of Health and Welfare, Jönköping University, SE-55111 Jönköping, Sweden. Tel: +46 705913908, e-mail: jan.dimberg@ju.se

Key Words: IL32, protein expression, SNP, colorectal cancer. controls and no relation to survival for any of the SNPs. However, the SNP rs12934561 was statisticalLY significant associated with older patients. IL32 protein was up-regulated in CRC tissue and related to IL6, TNF $\alpha$, and VEGF, and seems to be modulated by SNP rs28372698. The IL32 protein level in CRC tissue also reflects both disseminated disease and location. Conclusion. Our results suggest that altered IL32 protein concentrations in CRC tissue and genotypic variants of IL32 are related to disseminated CRC.

Worldwide, colorectal cancer (CRC) is a major cause of mortality and morbidity, and one of the most common types of cancer (1). Different genetic pathways which affect CRC initiation and progression have been described (2,3). Genetic variation, such as single nucleotide polymorphism (SNP), is important in individual variability in CRC susceptibility (4). The connection between inflammation and CRC initiation, progression and metastasis is well-established. Inflammation is driven by soluble factors such as cytokines and chemokines that are produced by tumor cells or cells recruited to the tumor microenvironment, such as lymphocytes $(5,6)$. Moreover, polymorphic variants of genes have been referred to as factors that mediate inflammatory response (7).

The search for molecular biomarkers to facilitate early diagnosis, determine prognosis and help in the selection of personalized therapy for patients with CRC is ongoing (8). It is well established that a subgroup of patients (20-25\%) with stage II CRC are at high risk for recurrence and should be considered as candidates for adjuvant chemotherapy (911). The decision to use adjuvant therapy could be made more rational using various genetic and molecular biomarkers to reveal subgroups of patients eligible for adjuvant therapy. The currently used clinical and pathological markers, such as poorly differentiated tumor, 
lymphovascular or perineural invasion, perforation, T4 growth, elevated carcinoembryonic antigen (CEA) level and fewer than 12 lymph nodes are removed, all have weak prognostic significance (9).

Interleukin 32 (IL32) is an intracellular pluripotent cytokine produced by epithelial cells, monocytes, Tlymphocytes and natural killer cells, and is involved in inflammation and cancer development (12). The gene encoding IL32 is located on the chromosome 16p13.3, organized into eight exons and consists of six splice variants $\alpha, \beta, \gamma, \delta, \varepsilon$ and $\xi$ (13). The specific function of IL32 is still not clear, however, it has been implicated in the pathogenesis of cancer and several inflammatory diseases (12). Diseases such as rheumatoid arthritis (14), chronic obstructive pulmonary disease (15), HIV infection (16), tuberculosis (17), inflammatory bowel disease (6), rhinosinusitis (18), stomach cancer (19), renal cancer (20) and CRC (21) are closely linked to IL32.

IL32 is able to induce the release a variety of proinflammatory cytokines such as IL8 (22), tumor necrosis factor- $\alpha(\mathrm{TNF} \alpha)(22,23)$ and IL6 (23). In addition, IL32 stimulates the production of vascular endothelial growth factor (VEGF) and thus has an indirect role in angiogenesis $(24,25)$.

Recent studies have shown an association between IL32 gene polymorphisms and several diseases. The intronic SNP rs12934561 has been reported as a susceptibility gene for acute lung injury (15) and endometrial cancer (26). An association of IL32 promoter SNP rs28372698, giving a higher expression of IL32 $\gamma$ has been found with thyroid carcinoma (27). Furthermore, another study demonstrated that a genetic variant of this SNP is associated with an increased risk of gastric cancer (28). IL32 promoter SNP rs4786370 has been suggested to have a possible protective role against cardiovascular disease (29).

The pathogenic and molecular mechanisms behind IL32 expression in CRC are largely unknown and not clear. This study aimed to investigate the association of IL32 gene polymorphisms rs28372698, rs12934561 and rs4786370 with CRC risk, cancer progression and long-term survival in Swedish patients with CRC. We also assessed the protein expression profile of IL32 in plasma and colorectal tissue, as well as analyzing colorectal tissue concentration of IL6, $\mathrm{TNF} \alpha$ and VEGF in patients with CRC.

\section{Materials and Methods}

Patients and controls. This study comprised a total of 465 patients (255 males and 210 females) with a mean age at diagnosis of 71 (range $=25-94$ ) years from south-eastern Sweden who underwent surgical resection for primary colorectal adenocarcinomas at the Department of Surgery, Ryhov County Hospital, Jönköping, Sweden between 1996-2016. The tumor localizations were in the colon in 245 and rectum in 220, and were classified according to the American Joint Committee on Cancer (AJCC) classification system
(3): stage I in 77 , stage II in 176 , stage III in 152 and stage IV in 60. Clinical information about the patients was obtained from the patient's computerized files which cover all the healthcare providers in the region. Follow-up ended on the date of death or on January $31,2016$.

Control blood donors $(n=331)$ were selected from individuals with no known CRC history at County Hospital Ryhov and were from the same geographical region as the patients. The group included 178 males and 153 females with a mean age of 59 (range $=33-68$ ) years.

Plasma samples. Of the patients and controls, 94 and 81, respectively, were available for IL32 protein analysis in plasma. Blood samples from the patients were drawn at the start of surgery and for the controls at the time of blood donation. All blood samples were centrifuged to separate plasma and blood cells and stored at $-78^{\circ} \mathrm{C}$ until analysis. The CRC patient group comprised 52 males and 42 females, with a mean age of 72 (range $=34-90$ years). Sixty-one tumors were located in colon and 33 in rectum and were classified as stage I in 20, stage II in 33, stage III in 22 and stage IV in 19. Controls for plasma samples included 39 males and 42 females, with a mean age of 54 (range $=41-68)$ years.

Tissue samples and lysates. This study utilized tumor and paired normal tissue samples available from 75 of the patients with CRC, of whom 43 were males and 32 females, with mean age 70 (range $=36-90$ ) years. The tumors were located in colon in 46 and in rectum in 29 , and were classified as stage I in six, stage II in 25 , stage III in 23 and stage IV in 21. Tumor tissue and adjacent normal mucosa (about $5 \mathrm{~cm}$ from the tumor) from each patient were excised and immediately frozen at $-78^{\circ} \mathrm{C}$ until analysis. Frozen tumor and paired normal tissue were thawed and homogenized in ice cold RIPA lysis buffer (Santa Cruz Biotechnology, Inc., Santa Cruz, CA, USA) containing a protease inhibitor cocktail according to the manufacturer's instructions. The lysate was placed on ice for $30 \mathrm{~min}$ and then centrifuged at $18,000 \times g$ for $10 \mathrm{~min}$. The protein content of the supernatant fluid was determined for each sample using the Bradford protein assay (Bio-Rad Laboratories, Hercules, CA, USA).

Paraffin-embedded tissue blocks. Formalin-fixed and paraffinembedded tumor samples were available from 73 patients with CRC and came from the archives of the Department of Pathology County Hospital Ryhov, Jönköping, Sweden. The group of patients with CRC comprised 41 males and 32 females, with a mean age 70 (range $=36-90$ ) years. The tumors were classified as stage I in six, stage II in 24, stage III in 23 and stage IV in 20 and were localized in colon in 44 and in rectum in 29.

Immunohistochemistry. From paraffin blocks, the selected tissue was assessed on 3.5- $\mu \mathrm{m}$ section on an automatic platform. Antigen retrieval was finished by coking for $52 \mathrm{~min}$ in Diva Decloaker, 10X (Biocare Medical, Concord, CA, USA) at $110^{\circ} \mathrm{C}$. Sections were treated with hydrogen peroxide for $5 \mathrm{~min}$ in order to block the occurrence of endogenous peroxidase which may disturb the interpretation of the color.

Primary rabbit polyclonal IL32 antibody against human IL32 $\alpha$, IL $32 \beta$ and IL32 $\gamma$ (Abcam, Tokyo, Japan) was used at dilution of 1:300. The antibody was applied to the tissue sections which were incubated for $30 \mathrm{~min}$ at room temperature. The MACH 4 Universal HRP-Polymer Detection kit (Biocare Medical) was used and the 
Table I. Genotypic frequencies of three interleukin 32 single nucleotide polymorphisms (SNPS) in patients with colorectal cancer and healthy controls.

\begin{tabular}{lcc}
\hline Genotype & $\begin{array}{c}\text { Patients }(\mathrm{n}=465), \\
\mathrm{n}(\%)\end{array}$ & $\begin{array}{c}\text { Healthy controls }(\mathrm{n}=331) \\
\mathrm{n}(\%)\end{array}$ \\
\hline $\mathrm{SNP}(\mathrm{rs} 28372698)$ & & \\
$\mathrm{T} / \mathrm{T}$ & $37.0(172)$ & $39.0(129)$ \\
$\mathrm{A} / \mathrm{T}$ & $47.7(222)$ & $49.2(163)$ \\
$\mathrm{A} / \mathrm{A}$ & $15.3(71)$ & $11.8(39)$ \\
$\mathrm{SNP}(\mathrm{rs} 12934561)$ & & \\
$\mathrm{C} / \mathrm{C}$ & $40.4(188)$ & $40.5(134)$ \\
$\mathrm{C} / \mathrm{T}$ & $45.4(211)$ & $40.8(135)$ \\
$\mathrm{T} / \mathrm{T}$ & $14.2(66)$ & $18.7(62)$ \\
$\mathrm{SNP}(\mathrm{rs} 4786370)$ & & \\
$\mathrm{T} / \mathrm{T}$ & $35.3(164)$ & $36.6(121)$ \\
$\mathrm{C} / \mathrm{T}$ & $47.5(221)$ & $49.5(164)$ \\
$\mathrm{C} / \mathrm{C}$ & $17.2(80)$ & $13.9(46)$ \\
\hline
\end{tabular}

reaction was visualized by Betazoid DAB Chromogen Kit (Biocare Medical). Splenic tissue was used as a positive control for IL32 expression and was included along with every patient tissue section.

An experienced pathologist evaluated IL32-stained sections and the staining intensity was scored on a scale of weak, moderate and strong.

Determination of IL32 level in tissue and plasma. Plasma and tissue IL32 levels were measured using a commercially available enzymelinked immunosorbent assay (ELISA) kit (R\&D Systems, Minneapolis, MN, USA) following the manufacturer's protocol. According to the product manual, the kit recognizes human IL32 $\alpha$, IL32 $\beta$ and IL32 $\gamma$. The tissue level of IL32 protein was expressed as picograms per milligram of protein and the plasma IL32 protein concentration from patients and controls was expressed as picograms per milliliter. All measurements including plasma, lysate and standard solutions for IL32 standard curves were performed in duplicates.

IL32 genotype determination. In the present study, genomic DNA was isolated from blood samples using QiaAmp DNA Kit (Qiagen, Hilden, Germany). DNA samples were genotyped using the TaqMan SNP assays of the IL32 SNPs rs28372698, rs12934561 and rs4786370 (Applied Biosystems, Foster City, CA, USA). DNA (10 ng) was mixed with Taqman Genotyping Master Mix (Applied Biosystems) and was amplified using the 7500 Fast Real-Time PCR system (Applied Biosystems). Amplification was performed using an initial cycle at $50^{\circ} \mathrm{C}$ for $2 \mathrm{~min}$, followed by one cycle at $95^{\circ} \mathrm{C}$ for $10 \mathrm{~min}$ and finally 40 cycles at $95^{\circ} \mathrm{C}$ for $15 \mathrm{~s}$ and at $60^{\circ} \mathrm{C}$ for $1 \mathrm{~min}$. The manual calling option in the allelic discrimination application ABI PRISM 7500 SDS software, version 1.3.1 (Applied Biosystems) was used to assign genotypes.

Quantification of IL6, TNF $\alpha$ and VEGF in tissue. The level of the cytokines IL6, TNF $\alpha$ and VEGF in colorectal tissue were measured in the prepared lysates using Luminex bead-based technology (BioRad Laboratories, Inc., Hercules, CA, USA) and commercially available Luminex assays for the cytokines (Bio-Rad Laboratories). The tissue level of IL32 protein was expressed as picograms per milligram of protein.

Statistical analysis. The differences in the frequencies of the IL32 gene polymorphisms between patients and controls and between clinical characteristics within the CRC subgroups were analyzed using chi-squared test. The Hardy-Weinberg equilibrium was assessed for the genotypes. The comparisons between groups regarding plasma and tissue levels of the measured cytokines were performed with non-parametric tests. The Wilcoxon's signed-rank test and the Mann-Whitney $U$-test were used for the analysis of the related and independent parameters. Statistical analyses were performed using SPSS software for Windows, version 14.0 (SPSS, Inc., Chicago, IL, USA). Survival analysis was performed by Kaplan-Meier analysis with the log-rank test and Cox's regression. Statistical analysis was performed using Stata Statistical Software: Release 13 (Stata Corp., College Station, TX, USA). Results were considered significant at $p<0.05$.

The investigation was approved by the Regional Ethical Review Board in Linköping, Linköping, Sweden (Dnr. 2013/271-31) and informed consent was obtained from each of the participants.

\section{Results}

IL32 gene polymorphism and CRC risk. The distribution of the genotypes for each polymorphism was in agreement with Hardy-Weinberg equilibrium. No significant differences in the genotypic frequencies (Table I) or in allelic frequencies (data not shown) were observed between the patients and the healthy controls for any of the SNPs. The genotypic distributions in the patient and the healthy control group were not associated with demographic characteristics such as age and gender, with the exception that patients carrying $\mathrm{C} / \mathrm{C}$ genotype for SNP rs12934561 $(\mathrm{n}=188)$ were significantly $(p=0.006)$ older [mean age $=72.2$ (range $=25-94)$ years] than $T$ carriers $(n=277)$ [mean age $=69.6$ (range $=29-90)$ years $]$. Stratification analysis of associations between individual SNP and patient's characteristics (Table II-IV) showed no significant differences, with the exception of age for SNP rs12934561 (Table III).

Protein levels of IL32, IL6, TNF $\alpha$, and VEGF in colorectal tissue. The levels of IL32 (Table V) and the other cytokines (Table VI) were significantly higher in tumor tissue compared to those in normal paired tissue. Evaluation of the relative expression (tumor $v s$. normal paired tissue) for IL32, IL6, TNF $\alpha$, and VEGF showed 84\% (63/75), 81\% (43/53), $65 \%(32 / 49)$ and $79 \%$ (38/48) up-regulation, respectively. Moreover, we noted the protein levels of IL32 and IL6, TNF $\alpha$, VEGF in cancer tissue, of the subset investigated, were significantly positively correlated $(\mathrm{r}=0.30, p=0.028$; $\mathrm{r}=0.29, p=0.044$; and $\mathrm{r}=0.43, p=0.003$, respectively; data not shown). There were no significant associations with clinical characteristics such as age, gender, stage and tumor location, except for IL32 where we observed significantly $(p=0.041$ higher levels in patients with rectal cancer [median $=1588$ 
Table II. Associations between interleukin 32 single nucleotide polymorphism rs 28372698 and clinicopathological features of colorectal cancer.

\begin{tabular}{|c|c|c|c|}
\hline \multirow[b]{2}{*}{ Characteristic } & \multicolumn{2}{|c|}{ Genotype } & \multirow[b]{2}{*}{$p$-Value } \\
\hline & $\mathrm{T} / \mathrm{T}$ & $\mathrm{A} / \mathrm{T}+\mathrm{A} / \mathrm{A}$ & \\
\hline Total number & 168 & 288 & \\
\hline Mean age (SD), years & $71.0(11.0)$ & $70.5(11.3)$ & 0.65 \\
\hline Men/women, $\mathrm{n}$ & $80 / 88$ & $124 / 164$ & 0.34 \\
\hline $\begin{array}{l}\text { Tumor localization, } \\
\text { Colon/rectum, n }\end{array}$ & $85 / 83$ & $157 / 131$ & 0.42 \\
\hline Stage, number, n (\%) & & & 0.69 \\
\hline I & $28(17)$ & $49(17)$ & \\
\hline II & $68(40)$ & $101(35)$ & \\
\hline III & $49(29)$ & $96(33)$ & \\
\hline IV & $23(14)$ & $42(15)$ & \\
\hline Excision $<12$ lymph nodes, n (\%) & $69 / 167(41)$ & $133 / 281(47)$ & 0.22 \\
\hline Low differentiated cancer, n (\%) & $35 / 162(22)$ & $65 / 274(24)$ & 0.38 \\
\hline Mucinous cancer, n (\%) & $16 / 162(10)$ & 40/274 (15) & 0.26 \\
\hline T4 tumor, $\mathrm{n}(\%)$ & $12 / 168(7)$ & 27/288 (9) & 0.78 \\
\hline Adjuvant treatment, n (\%) & $41 / 164(25)$ & $82 / 274(30)$ & 0.27 \\
\hline
\end{tabular}

Significant at $p<0.05$.

Table III. Associations between interleukin 32 single nucleotide polymorphism rs12934561 gene polymorphism and clinicopathological features of colorectal cancer.

\begin{tabular}{|c|c|c|c|}
\hline \multirow[b]{2}{*}{ Characteristic } & \multicolumn{2}{|c|}{ Genotype } & \multirow[b]{2}{*}{$p$-Value } \\
\hline & $\mathrm{C} / \mathrm{C}$ & $\mathrm{C} / \mathrm{T}+\mathrm{T} / \mathrm{T}$ & \\
\hline Total number & 185 & 271 & \\
\hline Mean age (SD), years & $72.2(11.2)$ & $69.7(11.1)$ & 0.016 \\
\hline Men/women, $\mathrm{n}$ & $88 / 97$ & $116 / 155$ & 0.32 \\
\hline $\begin{array}{l}\text { Tumor localization, } \\
\text { Colon/rectum, } \mathrm{n}\end{array}$ & $104 / 81$ & $138 / 133$ & 0.27 \\
\hline Stage, n $(\%)$ & & & 0.39 \\
\hline I & 35 (19) & $42(16)$ & \\
\hline II & $73(39)$ & $96(35)$ & \\
\hline III & $51(28)$ & $94(35)$ & \\
\hline IV & $26(14)$ & $39(14)$ & \\
\hline Excision $<12$ lymph nodes, $\mathrm{n}(\%)$ & $85 / 181(47)$ & $117 / 267(44)$ & 0.51 \\
\hline Low differentiated cancer, n (\%) & $39 / 177(22)$ & $61 / 259(24)$ & 0.52 \\
\hline Mucinous cancer, $\mathrm{n}(\%)$ & 23/177 (13) & $33 / 259(13)$ & 0.48 \\
\hline $\mathrm{T} 4$ tumor, $\mathrm{n}(\%)$ & $10 / 185(5)$ & $29 / 271(11)$ & 0.26 \\
\hline Adjuvant treatment, $\mathrm{n}(\%)$ & $44 / 178(25)$ & $79 / 260(30)$ & 0.19 \\
\hline
\end{tabular}

Significant at $p<0.05$.

(range $=508-5726) \mathrm{pg} / \mathrm{mg}$ ] compared to colon cancer [median=1333 (range=49-6057) pg/mg] (data not shown).

Plasma levels of IL32. The plasma levels of IL32 from 94 patients showed no significant difference in comparison with
Table IV. Associations between IL32 SNP rs4786370 gene polymorphism and clinicopathological features of colorectal cancer.

\begin{tabular}{|c|c|c|c|}
\hline \multirow[b]{2}{*}{ Characteristic } & \multicolumn{2}{|c|}{ Genotype } & \multirow[b]{2}{*}{$p$-Value } \\
\hline & $\mathrm{T} / \mathrm{T}$ & $\mathrm{C} / \mathrm{T}+\mathrm{C} / \mathrm{C}$ & \\
\hline Total number & 159 & 297 & \\
\hline Mean age (SD), years & $71.0(11.3)$ & $70.6(11.1)$ & 0.70 \\
\hline Men/women, $\mathrm{n}$ & $87 / 72$ & $165 / 132$ & 0.86 \\
\hline $\begin{array}{l}\text { Tumor localization, } \\
\text { Colon/rectum, n }\end{array}$ & $81 / 78$ & $161 / 136$ & 0.44 \\
\hline Stage, n $(\%)$ & & & 0.50 \\
\hline I & $23(14)$ & $54(18)$ & \\
\hline II & $66(42)$ & $103(35)$ & \\
\hline III & $48(30)$ & $97(33)$ & \\
\hline IV & $22(14)$ & $43(14)$ & \\
\hline Excision $<12$ lymph nodes, $\mathrm{n}(\%)$ & $66 / 158(42)$ & $136 / 290(47)$ & 0.30 \\
\hline Low differentiated cancer, $\mathrm{n}(\%)$ & $32 / 152(21)$ & $68 / 284(24)$ & 0.48 \\
\hline Mucinous cancer, n (\%) & $16 / 152(11)$ & 40/284 (14) & 0.43 \\
\hline $\mathrm{T} 4$ tumor, $\mathrm{n}(\%)$ & $9 / 159(6)$ & 30/297 (10) & 0.41 \\
\hline Adjuvant treatment, n (\%) & $39 / 154(25)$ & $84 / 284(30)$ & 0.34 \\
\hline
\end{tabular}

Significant at $p<0.05$.

81 healthy controls (Table V). There were no associations with clinical characteristics such as age, gender, stage and tumor location (data not shown).

Immunohistochemicall staining of IL32 in CRC tissue. Of the 73 patients, all cases exhibited positive membranous and cytoplasmic IL32 expression localized predominantly in cancer cells and comprising $50-100 \%$ of these cells. The evaluation of IL32 staining showed moderate staining in $56.2 \%$ (41/73) and strong staining in $43.8 \%$ (32/73) of tumor cases. The stromal tissue was not stained except for inflammatory cells, lymphocytes and macrophages that were identified by their morphological appearance. Representative immunostainings are in Figure 1.

Analysis of the association between IL32 staining and stages revealed significantly $(p=0.047)$ higher intense staining in patients with disseminated disease (stage III+IV) compared to patients with localized disease (stage I+II). The staining was not associated with other clinicopathological parameters such as age, gender and tumor location.

IL32 gene polymorphism in relation to the levels of IL32 in plasma and tissue. Overall, there were no associations between IL32 SNP variants and plasma IL32 levels in the patients with CRC and in the healthy controls. Otherwise, we noted that patients who were T/T carriers of SNP rs 28372698 $(\mathrm{n}=34)$ had a significantly $(p=0.025)$ lower IL32 level in CRC tissue [median $=1197$ (range $=49-2829) \mathrm{pg} / \mathrm{mg}$ ] compared with A carriers $(n=41)$ [median=1591 (range $=101$ 6057) $\mathrm{pg} / \mathrm{mg}$ ] (data not shown). 
Table V. Tissue and plasma levels of interleukin 32 (IL32) in patients with colorectal cancer and controls.

\begin{tabular}{lccc}
\hline Variable & Cases, $\mathrm{n}$ & IL32 protein & $p$-Value \\
\hline Tissue & & & \\
Cancer tissue & 75 & $1423(49-6057)$ & \\
Paired normal tissue & 75 & $765(7-4042)$ & $<0.001$ \\
Plasma & & & \\
Patients & 94 & $2113(9-532190)$ & \\
Controls & 81 & $2182(7-494010)$ & 0.613 \\
\hline
\end{tabular}

Data are shown as median (range) in tissue (pg/mg) and in plasma $(\mathrm{pg} / \mathrm{ml})$. Significant at $p<0.05$.

Table VI. The tissue levels of interleukin-6 (IL6) tumor necrosis factor$\alpha(T N F \alpha)$ and vascular endothelial growth factor (VEGF) in patients with colorectal cancer.

\begin{tabular}{lccc}
\hline Cytokine & Cases, $\mathrm{n}$ & Protein level $(\mathrm{pg} / \mathrm{mg})$ & $p$-Value \\
\hline IL6 & & & $<0.001$ \\
$\quad$ Cancer tissue & 53 & $39(5-780)$ & \\
$\quad$ Paired normal tissue & 53 & $12(2-262)$ & \\
TNF & & & 0.035 \\
$\quad$ Cancer tissue & 49 & $30(2-707)$ & \\
$\quad$ Paired normal tissue & 49 & $20(3-522)$ & \\
VEGF & 48 & $146(14-2187)$ & \\
$\quad$ Cancer tissue & 48 & $74(11-1725)$ & \\
$\quad$ Paired normal tissue & 48.001 \\
\hline
\end{tabular}

Data are shown as median (range) in tissue. Significant at $p<0.05$.
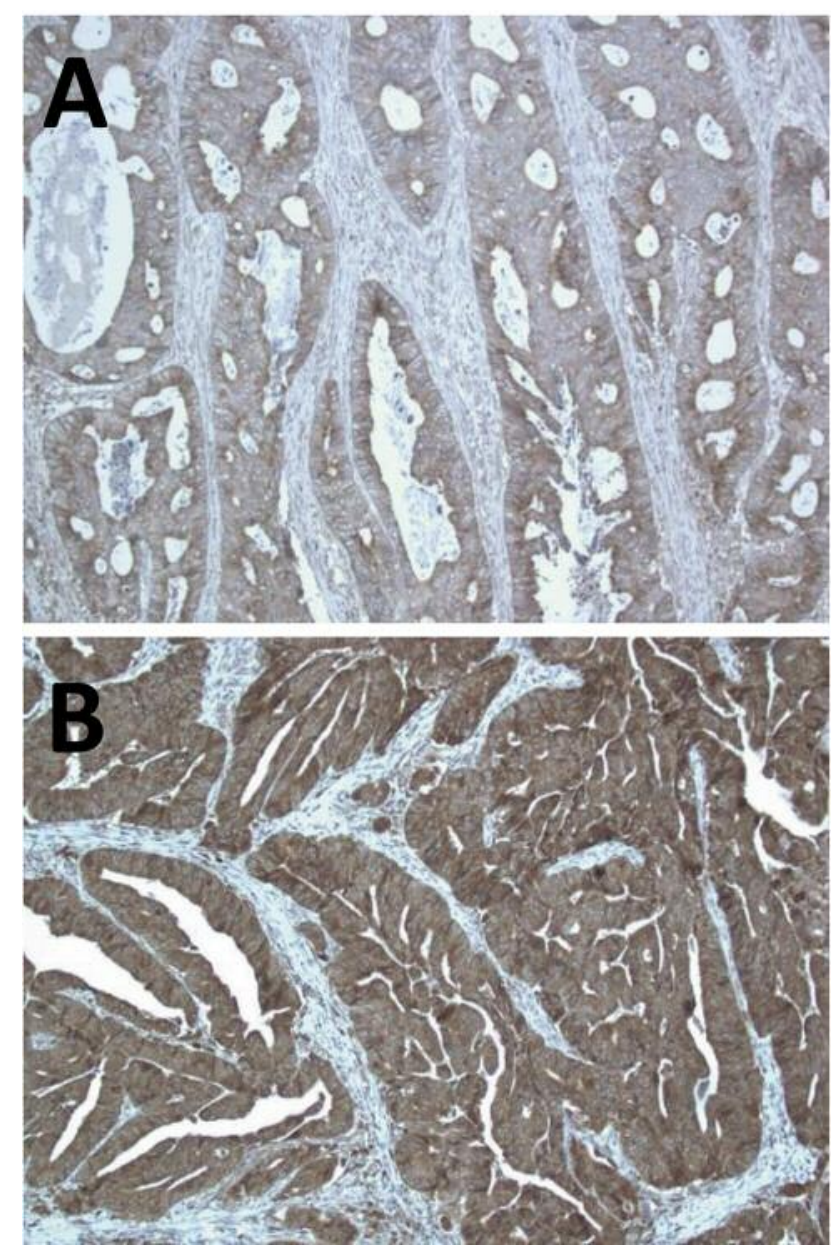

Figure 1. Immunohistochemical staining patterns for interleukin 32 in colorectal cancer: moderate $(A)$ and strong $(B)$ staining. Magnification, $\times 100$.

IL32 SNPs and survival analysis. Based on data from our cohort (Table II-IV) with up to 20 years of follow-up, the Kaplan-Meier analysis revealed no difference in cancerspecific and disease-free survival overall. Moreover, there was no difference in disease-free survival or in cancerspecific survival in any of the subsets according to TNM stage (data not shown).

\section{Discussion}

To our knowledge, there are limited studies about the role of IL32 gene polymorphisms in CRC susceptibility and survival status. Given the relation of IL32 gene polymorphisms rs28372698, rs12934561 and rs4786370 to other diseases $(15,26,28,29)$, we focused on these SNPs and found no significant differences in the genotypic frequencies between patients with CRC and healthy controls for any of the SNPs. The genotypic distributions in the patient and the healthy control groups were not associated with demographic characteristics such as age and gender, with the exception that patients carrying the C/C genotype for SNP rs12934561 were statistical significantly older at diagnosis than patients bearing other genotypes. One may speculate that this genotype may be involved in a mechanism via IL32 that enhances the antitumor effect of the immune system, with the result that patients are diagnosed at a higher age. However, the size of cases in the subgroups was relatively small and our findings should be interpreted with caution before being confirmed in further studies.

Stratification analysis of associations between individual SNP and patient's clinicopathological parameters showed no significant difference. Moreover, there was no difference in disease-free or in cancer-specific survival. This has not been previously reported to our knowledge. In previous studies, these investigated SNPs were indicated to be associated with 
cancer and inflammation-related diseases $(15,26,28,29)$, which supports the idea that polymorphisms have different functions in different diseases. It is possible that these SNPs differentially modulate the production of IL32 or different isoforms of IL32 which do not have biological effects in CRC. It is also possible that selected SNPs have a small effect that becomes undiscovered unless the study includes a larger sample size.

Inflammation can either promote or suppress CRC pathogenesis. Cytokines expressed in CRC cells or in the tumor microenvironment seem to play an important role in local immunoregulation $(5,6)$. Non-malignant cells in the microenvironment such as immune cells, fibroblasts and endothelial cells can promote and modulate CRC development by secretion of different cytokines (30). The roles of IL32 in CRC are little known and very few studies have been published, and the expression profile of IL32 protein in patients with CRC patients has not been fully evaluated. However, Yang et al. demonstrated by immunohistochemistry that IL32 stimulates metastasis to organs and lymph node metastasis of CRC (21). In this study, we noted that lysates from cancer tissue exhibited statistical significantly higher levels of IL32 protein compared to those in paired normal tissues. Moreover, we found that rectal cancer had significantly higher levels of IL32 protein in comparison to colon cancer but failed to detect associations with any other clinical characteristics. Hypothetically, different pathophysiological mechanisms may be involved in the progression of cancer in the colon and the rectum, resulting in different IL32 protein expressions. Possible differences in the carcinogenesis of colon and rectal carcinoma have been reported but whether these should be considered as two distinct entities remains controversial $(31,32)$.

IL6, TNF $\alpha$ and VEGF are considered to reflect the inflammatory response and have an impact on cancer development $(5,6)$. We investigated the concentration of these cytokines in lysates of CRC and paired normal tissue and found a statistically significantly higher concentration in cancer tissue. These findings are consistent with data from previous studies (33-35). Interestingly, we also noted a statistically significantly positively correlation between the level of IL32 and these cytokines. Studies have shown that IL32 increases the expression of these cytokines $(12,22,23)$. On the other hand, IL32 can be induced by TNF $\alpha$ and can on its own further potentiate TNF $\alpha$ expression (36).

Paradoxically, it has been found that IL32 plays different roles in different cell types and that some isoforms of IL32 are more active depending on cell types and show different abilities to induce inflammation and cancer $(12,36,37)$. Choi et al. demonstrated that IL $32 \gamma$ was the most potent at inducing the production of cytokines in macrophages (38). Subsequently, evidence has suggested that both IL $32 \alpha$ and
IL32 $\gamma$ seems to have anticancer effects by inhibiting colon cancer cell growth $(39,40)$.

In this study, it was critical to identify whether the elevated level of IL32 together with the other investigated cytokines in cancer tissue may have an impact on CRC development. In our study, we used an antibody against IL $32 \alpha$, IL $32 \beta$ and IL $32 \gamma$ and were unable to identify the other isoforms. However, the isoforms IL32 $\alpha$, IL32 $\beta$ and IL $32 \gamma$ are considered to be dominant (13) and our results reflect the total amount of IL32 expressed. We found no associations with clinical characteristics such as TNM stage, except that the IL32 level was significantly higher in rectal cancer compared to colon cancer tissues.

By using immunohistochemistry, we detected immunoreactivity of IL32 predominantly in cancer cells in all investigated cases. Analysis of the association between IL32 staining and TNM stage revealed statistical significantly higher intensiity of staining in patients with disseminated disease (stage III+IV) compared to patients with localized disease (stage I+II). We did not note this difference in the cancer lysates. This could be because cancer lysates also express IL32 derived from other cell types in the microenvironment and this masks difference in level of IL32 specifically expressed in the cancer cells as determined by immunohistochemistry. Further studies with more cases are warranted to investigate these issues. When assessing the potential relationship between the investigated SNPs and tissue concentration of IL32, we noted that patients who were T/T carriers for SNP rs28372698 had a statistically significantly lower IL32 level in CRC tissue compared with patients bearing other rs28372698 genotypes. It has been suggested from an association and functional study that this SNP is linked to thyroid carcinoma susceptibility and regulation of IL32 $\gamma$ expression (27). From these data, it can be interpreted that IL32 expression in CRC tissue can modulated by this SNP. Additional samples are required to demonstrate that genetic variation of IL32 SNP rs28372698 has an effect on the phenotype of tumors to explain, among other things, the immunohistochemical findings in this study.

We found that the difference in baseline serum IL32 concentration between patients with CRC and healthy controls was not statistically significant. The plasma IL32 level appears not to be useful as a biomarker for CRC. However, an extended study is required to clarify whether there is any difference in the expression of different IL32 isoforms between patients and controls.

The strength of this study is a well-characterized patient cohort with long follow-up time. The sample size of our study was the largest to date, but more patients would be needed to analyze associations between sub-groups with different clinical features. A further observation is that the CRC cases and controls were selected from one hospital, which may not be representative of other populations. 
However, both populations came from a defined geographical region which may represent the general population in Sweden well.

Up to now, there has been little information available about IL32 in CRC. In the present study, we report that no association was identified between rs28372698, rs12934561 or rs4786370 IL32 gene polymorphisms and CRC risk or survival. However, we noted that C/C for SNP rs12934561 was more frequent in elderly patients. Moreover, we observed that IL32 protein expression was up-regulated in CRC tissues compared to paired normal tissues and seems to be modulated by SNP rs28372698. The IL32 protein level also reflects both disseminated disease and location. The results presented in this study comprised the initial stage of forthcoming studies in our laboratory to determine whether IL32 and its isoforms have clinical relevance regarding CRC.

\section{Conflicts of Interest}

None.

\section{Acknowledgements}

This study was supported by grants from the Foundation of Clinical Cancer Research, Jönköping Sweden. The Authors thank Marita Skarstedt and Helena Nyström for their excellent technical support.

\section{References}

1 Haggar FA and Boushey RP: Colorectal cancer epidemiology: incidence, mortality, survival, and risk factors. Clin Colon Rectal Surg 22: 191-197, 2009.

2 Al-Sohaily S, Biankin A, Leong R, Kohonen-Corish M and Warusavitarne J: Molecular pathways in colorectal cancer. J Gastroenterol Hepatol 27: 1423-1431, 2012.

3 Markowitz SD and Bertagnolli MM: Molecular origins of cancer: Molecular basis of colorectal cancer. N Engl J Med 361: 2449-2460, 2009.

4 Mammano E, Belluco C, Bonafe M, Olivieri F, Mugianesi E, Barbi C, Mishto M, Cosci M, Franceschi C, Lise M. and Nitti D: Association of p53 polymorphisms and colorectal cancer: modulation of risk and progression. Eur J Surg Oncol 35: 415419, 2009.

5 Klampfer L: Cytokines, inflammation and colon cancer. Curr Cancer Drug Targets 11: 451-464, 2011.

6 Terzic J, Grivennikov S, Karin E and Karin M: Inflammation and colon cancer. Gastroenterology 138: 2101-2114, 2010.

7 Theodoropoulos G, Papaconstantinou I, Felekouras E, Nikiteas N, Karakitsos P, Panoussopoulos D, Lazaris A, Patsouris E, Bramis $\mathbf{J}$ and Gazouli $\mathrm{M}$ : Relation between common polymorphisms in genes related to inflammatory response and colorectal cancer. World J Gastroenterol 12: 5037-5043, 2006.

8 Yiu A J and Yiu CY: Biomarkers in colorectal cancer. Anticancer Res 36: 1093-1102, 2016.

9 Akiyoshi T, Kobunai T and Watanabe T: Recent approaches to identifying biomarkers for high-risk stage II colon cancer. Surg Today 42: 1037-1045, 2012
10 Bockelman C, Engelmann BE, Kaprio T, Hansen TF and Glimelius B: Risk of recurrence in patients with colon cancer stage II and III: a systematic review and meta-analysis of recent literature. Acta Oncol 54: 5-16, 2015.

11 O'Connor ES, Greenblatt DY, LoConte NK, Gangnon RE, Liou JI, Heise C P and Smith MA: Adjuvant chemotherapy for stage II colon cancer with poor prognostic features. J Clin Oncol 29: 3381-3388, 2011.

12 Hong JT, Son DJ, Lee CK, Yoon DY, Lee D H and Park MH: Interleukin 32, inflammation and cancer. Pharmacol Ther 174: 127-137, 2017.

13 Chen Q, Carroll HP and Gadina M: The newest interleukins: recent additions to the ever-growing cytokine family. Vitam Horm 74: 207-228, 2006.

14 Gui M, Zhang H, Zhong K, Li Y, Sun, J and Wang L: Clinical significance of interleukin-32 expression in patients with rheumatoid arthritis. Asian Pac J Allergy Immunol 31: 73-78, 2013.

15 Arcaroli JJ, Liu N, Yi N and Abraham E: Association between IL32 genotypes and outcome in infection-associated acute lung injury. Crit Care 15: R138, 2011.

16 El-Far M, Kouassi P, Sylla M, Zhang Y, Fouda A, Fabre T, Goulet JP, van Grevenynghe J, Lee T, Singer J, Harris M, Baril JG, Trottier B, Ancuta P, Routy J P, Bernard N and Tremblay C L: Proinflammatory isoforms of IL32 as novel and robust biomarkers for control failure in HIV-infected slow progressors. Sci Rep 6: 22902, 2016.

17 Bao F, Wen X, Liu A, Dai X, Zhao Q, Wang Y and Lu S: Elevated levels of serum IL32 in patients with active pulmonary tuberculosis. Afr J Microbiol Res 6: 7292-7294, 2012.

18 Keswani A, Kern RC, Schleimer RP and Kato A: Role of interleukin-32 in chronic rhinosinusitis. Curr Opin Allergy Clin Immunol 13: 13-18, 2013.

19 Seo EH, Kang J, Kim KH, Cho M C, Lee S, Kim H J, Kim JH, Kim E J, Park DK, Kim SH, Choi YK, Kim JM, Hong JT and Yoon DY: Detection of expressed IL32 in human stomach cancer using ELISA and immunostaining. J Microbiol Biotechnol 18: 1606-1612, 2008.

20 Lee HJ, Liang ZL, Huang SM, Lim JS, Yoon DY, Lee HJ and Kim JM: Overexpression of IL32 is a novel prognostic factor in patients with localized clear cell renal cell carcinoma. Oncol Lett 3: 490-496, 2012.

21 Yang Y, Wang Z, Zhou Y, Wang X, Xiang J and Chen Z: Dysregulation of overexpressed IL32 in colorectal cancer induces metastasis. World J Surg Oncol 13: 146, 2015.

22 Joosten LA, Heinhuis B, Netea MG and Dinarello CA: Novel insights into the biology of interleukin-32. Cell Mol Life Sci 70: 3883-3892, 2013.

23 Yousif NG, Al-Amran FG, Hadi N, Lee $\mathrm{J}$ and Adrienne $\mathrm{J}$ : Expression of IL32 modulates NF-kappaB and p38 MAP kinase pathways in human esophageal cancer. Cytokine 61: 223-227, 2013.

24 Tsai CY, Wang CS, Tsai MM, Chi HC, Cheng WL, Tseng Y H, Chen CY, Lin C D, Wu JI, Wang LH and Lin KH: Interleukin32 increases human gastric cancer cell invasion associated with tumor progression and metastasis. Clin Cancer Res 20: 2276$2288,2014$.

25 Nold-Petry CA, Rudloff I, Baumer Y, Ruvo M, Marasco D, Botti P, Farkas L, Cho SX, Zepp JA, Azam T, Dinkel H, Palmer BE, Boisvert WA, Cool CD, Taraseviciene-Stewart L, Heinhuis B, Joosten L A, Dinarello CA, Voelkel NF and Nold MF: IL32 promotes angiogenesis. J Immunol 192: 589-602, 2014. 
26 Yu X, Zhou B, Zhang Z, Gao Q, Wang Y, Song Y, Pu Y, Chen Y, Duan R., Zhang L and Xi M: Significant association between IL32 gene polymorphisms and susceptibility to endometrial cancer in Chinese Han women. Tumour Biol 36: 5265-5272, 2015.

27 Plantinga TS, Costantini I, Heinhuis B, Huijbers A, Semango G, Kusters B, Netea MG, Hermus A R, Smit JW, Dinarello CA, Joosten LA and Netea-Maier RT: A promoter polymorphism in human interleukin-32 modulates its expression and influences the risk and the outcome of epithelial cell-derived thyroid carcinoma. Carcinogenesis 34: 1529-1535, 2013.

28 Gonzalez-Hormazabal P, Musleh M, Bustamante M, Stambuk J, Escandar S, Valladares H, Lanzarini E, Chiong H, Rojas J, Castro VG, Rubio-Reyes C, Jara L and Berger Z: Role of cytokine gene polymorphisms in gastric cancer risk in Chile. Anticancer Res 34: 3523-3530, 2014.

29 Damen MS, Agca R, Holewijn S, de Graaf J, Dos Santos JC, van Riel PL, Fransen J, Coenen MJ, Nurmohamed MT, Netea MG, Dinarello CA, Joosten LA, Heinhuis B and Popa CD: IL32 promoter SNP rs4786370 predisposes to modified lipoprotein profiles in patients with rheumatoid arthritis. Sci Rep 7: 41629, 2017.

30 Peddareddigari VG, Wang D and Dubois RN: The tumor microenvironment in colorectal carcinogenesis. Cancer Microenviron 3: 149-166, 2010.

31 Konishi K, Fujii T, Boku N, Kato S, Koba I, Ohtsu, A, Tajiri H, Ochiai A and Yoshida S: Clinicopathological differences between colonic and rectal carcinomas: are they based on the same mechanism of carcinogenesis?. Gut 45: 818-821, 1999.

32 Lee YC, Lee YL, Chuang JP and Lee JC: Differences in survival between colon and rectal cancer from SEER data. PLoS One 8 : e78709, 2013

33 Komoda H, Tanaka Y, Honda M, Matsuo, Y, Hazama K and Takao T: Interleukin-6 levels in colorectal cancer tissues. World J Surg 22: 895-898, 1998.
34 Al Obeed OA, Alkhayal KA, Al Sheikh A, Zubaidi AM, VaaliMohammed M A, Boushey R, McKerrow JH and Abdulla MH: Increased expression of tumor necrosis factor-alpha is associated with advanced colorectal cancer stages. World J Gastroenterol 20: 18390-18396, 2014.

35 Cao D, Hou M, Guan YS, Jiang M, Yang Y and Gou HF: Expression of HIF-1alpha and VEGF in colorectal cancer: association with clinical outcomes and prognostic implications. BMC Cancer 9: 432, 2009.

36 Kim SH, Han SY, Azam T, Yoon DY and Dinarello CA: Interleukin-32: a cytokine and inducer of TNFalpha. Immunity 22: 131-142, 2005.

37 Heinhuis B, Plantinga TS, Semango G, Kusters B, Netea MG, Dinarello CA, Smit, JWA, Netea-Maier RT and Joosten L A B: Alternatively spliced isoforms of IL32 differentially influence cell death pathways in cancer cell lines. Carcinogenesis 37: 197205, 2016.

38 Choi JD, Bae SY, Hong JW, Azam T, Dinarello CA, Her E, Choi WS, Kim BK, Lee CK, Yoon DY, Kim SJ and Kim SH: Identification of the most active interleukin-32 isoform. Immunology 126: 535-542, 2009.

39 Oh JH, Cho MC, Kim JH, Lee SY, Kim HJ, Park ES, Ban JO, Kang JW, Lee DH, Shim JH, Han SB, Moon DC, Park YH, Yu DY, Kim JM, Kim SH, Yoon DY and Hong JT: IL32gamma inhibits cancer cell growth through inactivation of NF-kappaB and STAT3 signals. Oncogene 30: 3345-3359, 2011.

40 Yun HM, Park KR, Kim EC, Han, SB, Yoon DY and Hong JT: IL32alpha suppresses colorectal cancer development via TNFR1-mediated death signaling. Oncotarget 6: 9061-9072, 2015.

Received October 16, 2017

Revised October 31, 2017

Accepted November 1, 2017 